\title{
Mapping the Knowledge about the Gender of Company Executives
}

\author{
Mercedes Rodríguez-Fernández *(D), Eva M. Sánchez-Teba (D) and Juan Herrera-Ballesteros (D) \\ Department of Economics and Business Administration, Universidad de Málaga, 29071 Málaga, Spain; \\ emsanchezteba@uma.es (E.M.S.-T.); juanherrera@uma.es (J.H.-B.) \\ * Correspondence: mmrodriguez@uma.es
}

\begin{abstract}
The purpose of this paper is to analyze the literature on Gender and Company Executives with the purpose of identifying lines on which future research could be directed in order to eradicate gender differences in the decision-making bodies of companies. A bibliometric study has been carried out on the Web of Science collection, which, after a series of filters, has given rise to a sample of 144 articles from 1992 to 2018. Keywords and bibliographic references were the units of analysis used. With this information, bibliometric maps have been created applying the methodology of co-word and co-cite, clustering, and visualization techniques. The results suggest that this is an emerging scientific area not yet sufficiently developed, hinting at new research related to topics, such as career, gender diversity and performance, gender and leadership, organizational behavior and mobility, and gender and ethics. The emergence of the concept of "glass cliff" has been detected in the literature analyzed as a sign of the risk posed to women by the access to leadership positions.
\end{abstract}

Keywords: gender; company executives; bibliometric study

Citation: Rodríguez-Fernández, M.; Sánchez-Teba, E.M.;

Herrera-Ballesteros, J. Mapping the Knowledge about the Gender of Company Executives. J. Open Innov. Technol. Mark. Complex. 2021, 7, 15. https://doi.org/10.3390/joitmc7010015

Received: 14 December 2020 Accepted: 31 December 2020 Published: 5 January 2021

Publisher's Note: MDPI stays neutral with regard to jurisdictional clai$\mathrm{ms}$ in published maps and institutional affiliations.

Copyright: (C) 2021 by the authors. Licensee MDPI, Basel, Switzerland. This article is an open access article distributed under the terms and conditions of the Creative Commons Attribution (CC BY) license (https:// creativecommons.org/licenses/by/ $4.0 /)$.

\section{Introduction}

The current globalization of the economy generates, in the business world, a complex and uncertain environment that has led us to deepen the study of the Executives and their Gender as an adjuvant element that can give light and support the future of organizations. The subject matter of this work has its origin in events in the world of business today that have led to a thorough review of the literature on gender and executives since 1992.

As a result of this analysis, we have detected a wide variety of gender-related issues that are not solely confined to the field of business management. Politics, psychology, or ethics are some of the fields that deal with gender without referring to the organization of companies ([1-5]). Amongst all of them, we can highlight ethics as the issue that dominates the majority over the rest. Authors, such as [6], analyze leadership from a cultural and moral perspective.

In general terms, gender is dealt together with other issues, such as ethnicity, religion, socio-economic classes, or exclusion groups, which leads us to think that gender can also be an indicator of discrimination in the working environment. It is the case of [7], who analyze the subject of obesity and success in the field of business, recognizing that it can become a stigma within the organization, preventing the rise in the hierarchy.

We understand that the study of gender in executives should not respond to fashions or the intensity of social demands or public opinion, but rather to the challenges and demands of a balanced and compensated society. Recently, studies focused on business have detected differences in the ways that men and women work at the management level [8] examine how ambidextrous managers in small and medium enterprises craft their tasks as a strategy for open innovation to enhance business performance providing a novel explanation of the relationship between manager ambidextrous behavior and business performance through the mediation of job crafting among top managers with a global view of gender. Besides, at the board level, numerous authors have examined gender within the 
diversity that is found in top management teams $[9,10]$, which indicates that it is a theme with total validity.

With these ideas in mind, the authors of this paper have set, as an objective, to analyze the literature on gender of the company executives with the purpose of identifying lines on which future research could be directed in order to eradicate gender differences in the decision-making bodies of companies.

This work is structured, as follows: firstly, we offer the bibliometric analysis section where we present the analysis performed on co-words and co-quotes. We include the methodological parameters and temporal evolution of the analyzed production. Subsequently, in Section 3, we include literature review, where an analysis of the evolution of the subject on "executives and gender" is performed and the main articles are commented. In Section 4, the results of the work are presented, differentiating between co-word and co-citation analysis and their corresponding mapping. Likewise, the cluster type analysis is presented. Finally, the paper closes with the discussion and conclusions of this study.

\section{Bibliometric Analysis}

The use of the bibliometric technique is justified for two main reasons: firstly, we consider that it is a scientifically endorsed wide range technique and, secondly, due to its objective nature, the aim has been to eliminate the possible partiality that is inherent to the "Executives and Gender" theme. Consequently, the result of the research work does not respond to a temporary fashion, but to the challenge that is imposed by today's society.

This investigation began in June 2018. A first search was made of the main collection of Web of Science (WOS). The word search included the terms *gender and *executives without limiting it to a certain period of time. Only scientific articles were taken into account, discarding any other type of publication. Those journals indexed in listings, such as Journal Citation Reports (JCR), Scimago Journal \& Country Rank (SJR), and Scopus, were considered. In addition, it was refined by three main categories: Business, Management, and Woman Studies. That search gave us a result of 199 articles with which we began to work.

\begin{tabular}{|c|c|c|}
\hline 1st phase & 2nd phase & 3rd phase \\
\hline $\begin{array}{l}\text { *gender and } \\
\text { *executives } \\
\text { without limiting } \\
\text { it to a certain } \\
\text { period of time }\end{array}$ & $\begin{array}{l}\text { Filter: } \\
\text { - } \quad \text { Articles } \\
\text { Business, } \\
\text { Management a } \\
\text { Woman studies }\end{array}$ & $\begin{array}{l}\text { Review of } 158 \text { abstracts one } \\
\text { by one, eliminating all of the } \\
\text { documents with titles or } \\
\text { abstracts on other subjects. }\end{array}$ \\
\hline 199 papers & 158 articles & 144 articles selected \\
\hline
\end{tabular}

Figure 1. Outline of the methodology followed. * The Web of Science search included these terms.

Subsequently, it was decided to make a new filter in WOS, this time limiting the results to the editions of Social Science Index (SCI) and Social Science Citation Index (SSCI), focusing even more on the economic field. After this second search, the final number of articles remained at 158. Throughout the investigation we detected that of these, 14 of them indicated "gender" as a keyword in the additional keywords and not in the main ones; exploring the content of these articles. it was observed that, in no case, did they deal with this subject matter, so it was finally decided to limit the analysis to 144 papers (Figure 1). Initially, in the bibliometric study, 144 articles were analyzed, classified by article 
types (theoretical/empirical), data sources (survey, database, interview, others), sample size, analysis techniques, and type of research (qualitative/quantitative). As the Table 1 in Methodological Parameters shows, most of the studies are theoretical and the type of research is quantitative. The main source of the data is the survey, with $44.92 \%$. The samples used in the literature reviewed were below 1000 cases in $75.66 \%$. The most commonly used technique is regression with $46.55 \%$, followed by other quantitative techniques.

Table 1. Methodological parameters.

\begin{tabular}{|c|c|c|c|c|c|}
\hline Type of Research & $\%$ & Sample & $\%$ & \multirow{2}{*}{ Analysis Technique } & \multirow{2}{*}{$\%$} \\
\hline Quantitative & 74.6 & $<100$ & 27 & & \\
\hline Qualitative & 22.9 & $<1000$ & 48.7 & Regression & 46.6 \\
\hline Quantitative/qualitative & 2.55 & $>1000$ & 24.3 & Correlation & 9.48 \\
\hline Total & 100 & Total & 100 & Descriptive & 6.03 \\
\hline Type of Article & $\%$ & Source & $\%$ & Factor analysis & 5.17 \\
\hline \multirow{2}{*}{ Theoretical study } & \multirow{2}{*}{89} & Survey & 44.9 & Anova & 4.31 \\
\hline & & Databases & 33.9 & Manova & 2.59 \\
\hline \multirow{2}{*}{ Empirical study } & \multirow{2}{*}{11} & Interview & 14.4 & Other quantitative techniques & 25.9 \\
\hline & & Other & 6.77 & & \\
\hline Total & 100 & Total & 100 & Total & 100 \\
\hline
\end{tabular}

Source: Prepared by the authors.

Temporal evolution of the analyzed production is increasing, as can be seen in Figure 2. From 1992 to 2018, the number of articles per year has suffered significant ups and downs, although, if the trend line is traced, it progresses steadily. Thus, the first article was registered during 1992, ending in 2018, with 14 articles. It is necessary to emphasize peaks in the ascending line as those of the year 1997 with five articles or 2008 with 10 articles. Descending peaks included one article in 1999, three articles in 2006, four articles in 2012, and seven articles in 2017. There has been a sharp change between 2017 and 2018, as the number of articles on "Executives and Gender" has doubled.

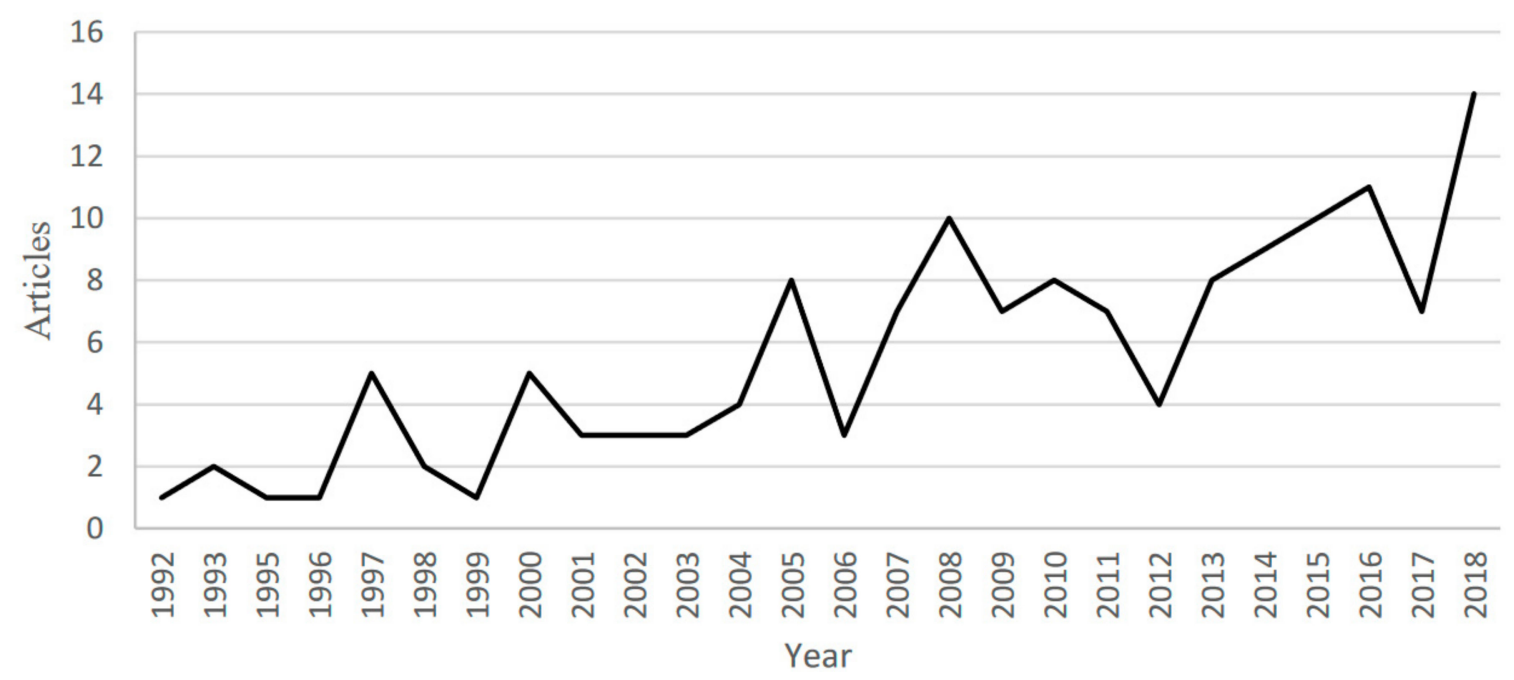

Figure 2. Number of articles published per year. Source: Prepared by the authors.

In the search for the causes that may have provoked this significant increase, the world press has been explored in order to find economic, legal, or social explanations. Globally, the appearance of the "me too" movement in October 2017 in the USA may have led to a boom in research interest about gender issues. 


\section{Analysis of Co-Words and Co-Cites}

The bibliometric technique has been completed with an analysis of co-words and co-cites. Co-words analysis measures documentary similarity through word analysis; basically, this method consists of detecting words that represent concepts of documents in a scientific domain and relates the documents in which they appear, according to their degree of co-occurrence. This procedure aims to study the thematic, semantic, conceptual, and cognitive structures within a research area $([11,12])$.

The analysis of co-citas measures the similarity between documents based on the bibliographical references of the same, is directed fundamentally to the study of the aspects of the intellectual structure or knowledge base of a research area $([13,14])$. This analysis helps us to determine the evolution of trends in the study of the subject matter under analysis.

In addition, the VOSviewer software allows for the representation of the conceptual structure of a research field while using bibliometric maps. Because of the multidisciplinary character in which the theme "Executives and Gender" can be found, such a representation improves the global understanding of the object under investigation.

\section{Literature Review}

Some recent publications that are considered to be of relevance, both in terms of their subject matter and the number of citations received, stand out from the body of research. The first of the analyzed researches dates from 1992, it is the publication of [15], where it looks for the causes that originate the resignations in the work environment. This article is published by Journal of Organizational Behaviour; although, this journal does not continue in this same line, since it only has $2 \%$ of the total production analyzed.

Among the latest publications, we include [16] on the gender pay gap amongst executives. These authors study the case of Australian companies and conclude that, in order to achieve gender equality, the proportion of women at executive levels and the wage gap must be controlled. In this line, Chaudhary [17] recently analyzed the impact of employees' perception of their employer's corporate social responsibility (CSR) on their in-role and extra-role behaviors, including gender as an important variable in India. Similarly, [18] highlight the successful ascent of female leaders in the pharmaceutical industry.

Two articles from The Leadership Quarterly stand out throughout the scientific production, extending the analysis of the phenomenon known as "glass cliffs". On the one hand, there is the work of [19] entitled "Leading at the top: Understanding women's challenges above the glass", which analyzes the conditions under which women are promoted to leadership positions. Until this work, very few researchers addressed the context of women's promotion to leadership positions. On the other hand, we highlight the study by [20], where a review of a decade of research on the same phenomenon is carried out, reaching the conclusion that it is a complex issue, which is closely related to the context, robust, and generalized, in addition to being a notable characteristic in the organizational panorama of companies. Academy of Management publishes the work of [21], where he explains the differences between men and women in terms of performance and perceived rewards. The theme of work-family balance is recognized by the Harvard Business Review with the publication of [22] "Manage Your Work, Manage Your Life", where they extract gender differences in terms of professional success.

In the time interval 1997 to 2008, some articles stand out due to their subject matter, such as [23], which gathers the motivations that guide enterprising women to establish themselves as entrepreneurs and abandon their jobs in large companies; among them, balancing their work and family life, as well as the desire to fulfil a challenge. In the case of [24], compare the careers of 69 executives of both genders, concluding that the probability of success for women was lower than for men.

On the other hand [25] address the gender pay gap on boards of directors in the case of British listed companies, even corroborating this inequity. The case of [26] draws attention to the Swedish case and points out that, despite the apparent equality at senior management levels, only one woman per company is given in Sweden, while in non-Swedish companies 
this value is doubled. Additionally, ref [27] suggest that improving financial performance for companies with more female executives does not occur through revenue management, but is positively associated with ethics in the way that women executives act.

The last of the articles in the sample analyzed was published in 2018 by [28] and it deals with the relationship between the profit measured in terms of ROA (Returns on Assets) and the demographic characteristics of CEOs (Chief Executive Officers). It has been published by the Journal of Small Business Management, which does not usually include this topic among the usual ones, since it only has two articles in the total of the studied production, the first of them in 1997.

\section{Results}

Of the total of the analyzed production, 144 articles, we emphasize, in first place, that 132 of them are written by first authors who have only published one investigation. This gives us a first idea of the wide dispersion amongst authors that exists in this matter.

Another result of interest is the number of articles per author and its corresponding index $\mathrm{H}$, according to the Web of Science, which indicates to us, as can be seen in Table 2, that Lyness, with four articles, is the most prolific author in this field. It also has a high $\mathrm{H}$ index that is equal to 16 , only being surpassed by Ryan, with 22 , who has only published two articles on this subject.

Table 2. Number of articles by author and author's index H.

\begin{tabular}{ccc}
\hline Author & I. H. & Item No. \\
\hline Lyness, K.S. & 16 & 4 \\
De Anca, C. & 3 & 2 \\
Ryan, M.K. & 22 & 2 \\
Baixauli-Soler, J.S. & 1 & 2 \\
Gould, J.A. & 1 & 2 \\
Other authors & - & 132 \\
\hline
\end{tabular}

Source: Prepared by the authors.

It has been possible to verify, with this information, the extent to which the Lotka law that is applicable to studies of this type is complied with. Thus, the formula that predicts production by author is expressed as $\mathrm{Y}=\mathrm{K} / \mathrm{Xn}$, where $\mathrm{K}$ is the total of authors, $\mathrm{X}$ is the largest number of articles published by author, $\mathrm{Y}$ is the number of authors who publish articles on that subject, and $\mathrm{n}$ is a constant with a value equal to 2 . In our case, $\mathrm{K}$ is equal to 137 authors and $X$ is four articles, from which it is obtained that the prediction of Lotka for $\mathrm{Y}$ is 8.6. As noted in Table 2, we have only found five authors that publish more than one article, suggesting that we are dealing with an emerging area not yet developed by a sufficient number of authors.

Another result of interest is the categorization of all scientific production based on topics that are frequently repeated (see Table 3). They stand out from the rest "Gender diversity", "Ethics", "Work-life balance", or "Gender and HR". Specifically, "Gender and Promotion" appears in 14 articles and mostly in the period 2000 to 2009. It is followed by "Gender diversity" 11 times.

With respect to the journals that are interested in the production object of this study, we highlight the Journal of Business Ethics (2nd quartile JCR), with 13\% of it and 18 of the 144 articles. The remainder are very atomized, which indicates that none of the journals specialized in this subject as can be seen in Table 4 .

The bibliographic production by country (Table 5 ) indicates that the USA leads the research in this field, with a total of 81 articles, which represents $56.25 \%$ of the total. England follows at a great distance with 12 articles. Spain ranks fourth with six articles, five of which have been written between 2010-2018. 
Table 3. Evolution of the relevance of the subjects dealt with in the literature on gender and executives.

\begin{tabular}{|c|c|c|c|c|}
\hline Topics & Total & 1992-1999 & 2000-2009 & 2010-2019 \\
\hline TOTAL & 144 & 13 & 46 & 85 \\
\hline Gender and promotion & 14 & 2 & 7 & 5 \\
\hline Gender diversity & 11 & & 4 & 7 \\
\hline Ethics & 11 & 1 & 7 & 3 \\
\hline Work-life balance & 10 & & 4 & 6 \\
\hline Gender and HR & 10 & & 2 & 8 \\
\hline gender pay gap & 9 & & 4 & 5 \\
\hline Gender leadership & 8 & 1 & 3 & 4 \\
\hline Earnings & 7 & & 1 & 6 \\
\hline Reward systems/compensation & 5 & & & 5 \\
\hline Gender and risks & 5 & & & 5 \\
\hline Gender and policy & 4 & & & 4 \\
\hline Gender gap & 4 & & & 4 \\
\hline Glass Cliff & 4 & & 1 & 3 \\
\hline Demographic factors & 3 & 3 & & \\
\hline Gender, ethnicity and race & 3 & & 1 & 2 \\
\hline Gender and organizational factors & 3 & & 2 & 1 \\
\hline CSR & 2 & & 1 & 1 \\
\hline Gender and stereotype & 2 & & 1 & 1 \\
\hline Glass Ceiling & 2 & & 1 & 1 \\
\hline Gender and training & 2 & & & 2 \\
\hline Gender and communication & 2 & & & 2 \\
\hline Gender and values & 2 & & & 2 \\
\hline Gender and performance & 2 & 2 & & \\
\hline Exclusion barriers & 2 & & & 2 \\
\hline Gender and resignation from the position & 2 & 1 & 1 & \\
\hline Other & 15 & 3 & 6 & 6 \\
\hline
\end{tabular}

Source: Prepared by the authors. Extracted from Web Of Science.

Table 4. JCR Listed Journals by Quartile.

\begin{tabular}{|c|c|c|c|c|c|c|}
\hline Journals & Q1 & Q2 & Q3 & Q4 & $\begin{array}{l}\text { Tot } \\
\text { Art. }\end{array}$ & $\%$ \\
\hline Journal of Business Ethics & & $x$ & & & 18 & $13 \%$ \\
\hline Human resource management & & $x$ & & $x$ & 5 & $3 \%$ \\
\hline Corporate governance-an international review & $x$ & $x$ & & & 5 & $3 \%$ \\
\hline International Journal of Manpower & & & & $x$ & 5 & $3 \%$ \\
\hline Strategic management journal & $\mathrm{x}$ & & & & 4 & $3 \%$ \\
\hline $\begin{array}{c}\text { International Journal of Human Resource } \\
\text { Management }\end{array}$ & & $\mathrm{x}$ & & & 4 & $3 \%$ \\
\hline Journal of management & $\mathrm{x}$ & & & & 3 & $2 \%$ \\
\hline Human relations & & $\mathrm{x}$ & & & 3 & $2 \%$ \\
\hline Journal of women politics \& policy & & & $\mathrm{x}$ & $x$ & 3 & $2 \%$ \\
\hline British Journal of Management & & $x$ & & & 3 & $2 \%$ \\
\hline Journal of Business Research & & $x$ & & & 3 & $2 \%$ \\
\hline Academy of Management Executive & & $x$ & & & 3 & $2 \%$ \\
\hline Journal of Organizational Behavior & $x$ & & & & 3 & $2 \%$ \\
\hline Gender Work and Organization & & $x$ & & & 3 & $2 \%$ \\
\hline Leadership quarterly & $\mathrm{x}$ & & & & 3 & $2 \%$ \\
\hline Harvard business review & $x$ & & & & 3 & $2 \%$ \\
\hline Administrative science quarterly & $x$ & & & & 3 & $2 \%$ \\
\hline
\end{tabular}

Source: Prepared by the authors.

Table 6 shows the evolution of bibliographic production by country, relating it to the quartile in which the journals are indexed. USA, England, and Australia have their highest production in quartile Q2. Spain, for instance, has it divided 50\% between Q2 and Q3. 
Table 5. Bibliographic production by country and period.

\begin{tabular}{|c|c|c|c|c|}
\hline Country & Total & 1992-1999 & 2000-2009 & 2010-2018 \\
\hline TOTAL & 144 & 13 & 46 & 85 \\
\hline USA & 81 & 10 & 27 & 44 \\
\hline England & 12 & 1 & 6 & 5 \\
\hline Australia & 7 & & 3 & 4 \\
\hline Spain & 6 & & 1 & 5 \\
\hline China & 5 & & & 5 \\
\hline Canada & 3 & & 2 & 1 \\
\hline France & 3 & & 1 & 2 \\
\hline Switzerland & 2 & & & 2 \\
\hline Italy & 2 & & 1 & 1 \\
\hline Denmark & 2 & & & 2 \\
\hline Germany & 2 & & 1 & 1 \\
\hline Ireland & 2 & 1 & 1 & \\
\hline New Zealand & 2 & & & 2 \\
\hline Scotland & 1 & & & 1 \\
\hline Sweden & 1 & & 1 & \\
\hline South Africa & 1 & & & 1 \\
\hline Taiwan & 1 & & & 1 \\
\hline Finland & 1 & & 1 & \\
\hline Brazil & 1 & & & 1 \\
\hline Singapore & 1 & & & 1 \\
\hline Nigeria & 1 & & & 1 \\
\hline Israel & 1 & & 1 & \\
\hline Oman & 1 & & & 1 \\
\hline Hong Kong & 1 & 1 & & \\
\hline Pakistan & 1 & & & 1 \\
\hline Poland & 1 & & & 1 \\
\hline Netherlands & 1 & & & 1 \\
\hline Malaysia & 1 & & & 1 \\
\hline
\end{tabular}

\subsection{Co-Word Analysis Results}

VOSviewer is the program used, which focuses on the visualization of distance-based bibliometric networks that supports a large number of metadata.

In order to visualize the bibliometric network, the program works with different units of analysis (authors, organizations, countries, documents, source-journals, keywords, cited references, cited author, or cited source-journals) and units of measurement (co-authorship, co-occurrence, citation).

In order to obtain a visualization, VOSviewer applies the association force normalization technique, the VOS mapping technique (visualization of similarities), and, finally, the grouping technique. A cluster is a set of closely related nodes according to the type of linkage being analyzed; each node is assigned to exactly one cluster.

For this type of analysis, the keywords of the published articles are used as the unit. As a result, we obtain two types of maps: one that describes the network of links between keywords (Figure 3) and another, called density map, where we can see the intensity of use of the different keywords (Figure 5). For the network map, a minimum of five occurrences per keyword was chosen and resulted in 59 keywords out of a total of 963 . For each of the keywords, the total strength of the co-occurrence links with other keywords was calculated. The keywords were selected with the highest total link strength.

A hierarchical grouping using an average link has been used in order to identify groups of strong cohesive links between words. In Figure 3, we can visually see the network of links between the main keywords defined by curved lines of different colors that converge in nodes. Each node is one of the 59 keywords and each color corresponds to the same group or cluster. The size of the keywords determines a greater or lesser number of apparitions. 
Table 6. The evolution of the relevance of the subjects dealt with in the literature on gender and executives.

\begin{tabular}{|c|c|c|c|c|c|c|c|c|c|c|}
\hline \multirow{2}{*}{$\begin{array}{c}\text { Country } \\
\text { TOTAL }\end{array}$} & \multicolumn{2}{|c|}{ Total } & \multicolumn{2}{|c|}{ Q1 } & \multicolumn{2}{|c|}{ Q2 } & \multicolumn{2}{|c|}{ Q3 } & \multicolumn{2}{|c|}{ Q4 } \\
\hline & 144 & Total & 40 & Country & 66 & Country & 18 & Country & 20 & Country \\
\hline USA & 81 & $56 \%$ & 31 & $38 \%$ & 37 & $46 \%$ & 7 & $9 \%$ & 6 & $7 \%$ \\
\hline England & 12 & $8 \%$ & 3 & $25 \%$ & 6 & $50 \%$ & 3 & $25 \%$ & & \\
\hline Australia & 7 & $5 \%$ & & & 6 & $86 \%$ & & & 1 & $14 \%$ \\
\hline Spain & 6 & $4 \%$ & & & & & 3 & & 3 & \\
\hline China & 5 & $3 \%$ & 2 & $40 \%$ & 1 & $20 \%$ & 1 & $20 \%$ & 1 & $20 \%$ \\
\hline Canada & 3 & $2 \%$ & & & 1 & $33 \%$ & & & 2 & $67 \%$ \\
\hline France & 3 & $2 \%$ & 2 & $67 \%$ & 1 & $33 \%$ & & & & \\
\hline Switzerland & 2 & $1 \%$ & 1 & $50 \%$ & 1 & $50 \%$ & & & & \\
\hline Italy & 2 & $1 \%$ & & & & & & & 2 & $100 \%$ \\
\hline Denmark & 2 & $1 \%$ & 1 & $50 \%$ & & & & & 1 & $50 \%$ \\
\hline Germany & 2 & $1 \%$ & & & 2 & $100 \%$ & & & & \\
\hline Ireland & 2 & $1 \%$ & & & 2 & $100 \%$ & & & & \\
\hline New Zealand & 2 & $1 \%$ & & & 2 & $100 \%$ & & & & \\
\hline Scotland & 1 & $1 \%$ & & & 1 & $100 \%$ & & & & \\
\hline Sweden & 1 & $1 \%$ & & & & & & & 1 & $100 \%$ \\
\hline South Africa & 1 & $1 \%$ & & & & & & & 1 & $100 \%$ \\
\hline Taiwan & 1 & $1 \%$ & & & & & & & 1 & $100 \%$ \\
\hline Finland & 1 & $1 \%$ & & & 1 & $100 \%$ & & & & \\
\hline Brazil & 1 & $1 \%$ & & & & & 1 & $100 \%$ & & \\
\hline Singapore & 1 & $1 \%$ & & & 1 & $100 \%$ & & & & \\
\hline Nigeria & 1 & $1 \%$ & & & & & 1 & $100 \%$ & & \\
\hline Israel & 1 & $1 \%$ & & & 1 & $100 \%$ & & & & \\
\hline Oman & 1 & $1 \%$ & & & & & 1 & $100 \%$ & & \\
\hline Hong Kong & 1 & $1 \%$ & & & 1 & $100 \%$ & & & & \\
\hline Pakistan & 1 & $1 \%$ & & & 1 & $100 \%$ & & & & \\
\hline Poland & 1 & $1 \%$ & & & & & & & 1 & $100 \%$ \\
\hline Netherlands & 1 & $1 \%$ & & & 1 & $100 \%$ & & & & \\
\hline Malaysia & 1 & $1 \%$ & & & & & 1 & $100 \%$ & & \\
\hline
\end{tabular}

Source: Prepared by the authors. Extracted from Web Of Science.

Figure 4 has been elaborated in order to better clarify the relationship of all the selected keywords, where the color assigned to each cluster has been specified with the intention of being able to appreciate the themes that intertwine with each other, giving rise to a relationship of concepts that point us to a series of ideas on which we are researching. Thus, cluster 1 focuses on research regarding diversity and its impact on corporations, cluster 2 is more oriented to research about power and gender leadership in organizations, while cluster 3 is involved in issues of wage discrimination, compensation, and mobility within organizations, and, finally, cluster 4 is focused on issues related to cultural, value or ethical aspects.

Table 7 has been prepared in order to identify the keywords that have a greater occurrence. It can be observed that "gender" and "women" are the first of their clusters (cluster 4 and cluster 3, respectively) and they have the greatest number of occurrences, later followed by "management" and "executives" that also belong to these clusters. In position 6 and 7 are leadership and performance, which are part of clusters 2 and 1, respectively. These data are corroborated by the bibliometric density map. 


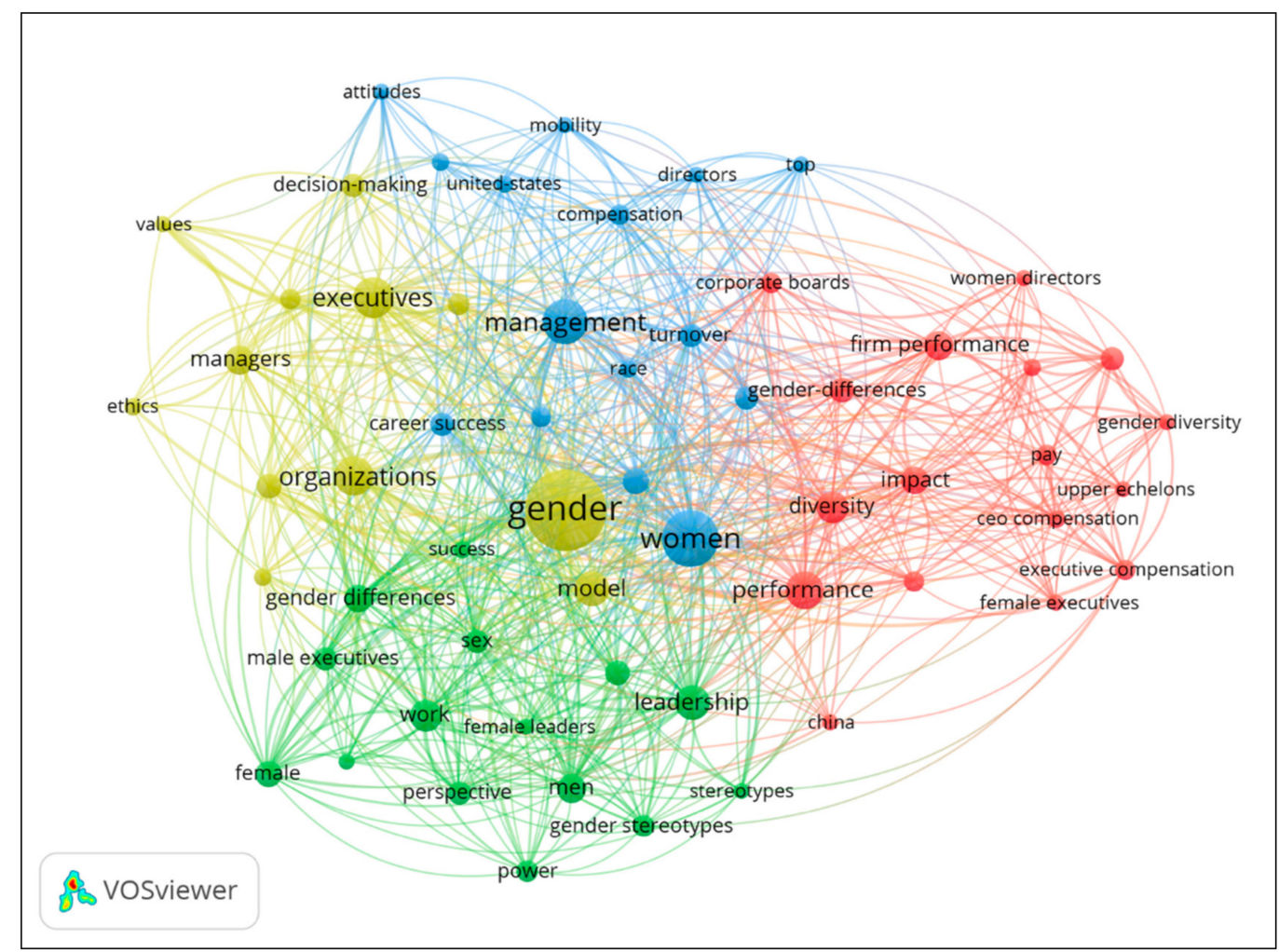

Figure 3. Network of links between keywords. Source: Prepared by the authors.

\begin{tabular}{|c|c|c|c|}
\hline $\begin{array}{l}\text { Cluster } 1 \\
\text { Diversity }\end{array}$ & $\begin{array}{l}\text { Cluster } 2 \\
\text { Gender power and } \\
\text { leadership }\end{array}$ & $\begin{array}{c}\text { Cluster } 3 \\
\text { Salary discrimination, } \\
\text { compensation and mobility }\end{array}$ & $\begin{array}{c}\text { Cluster } 4 \\
\text { Culture, values and } \\
\text { ethics }\end{array}$ \\
\hline & $\checkmark$ & & \\
\hline$\square$ ceo compensation & $\square$ commitment & $\square$ attitudes & $\square$ behavior \\
\hline$\square$ china & $\square$ female & $\square$ career success & $\square$ business ethics \\
\hline$\square$ corporate boards & $\square$ female leaders & $\square$ compensation & $\square$ culture \\
\hline$\square$ corporate governance & $\square$ gender differences & $\square$ directors & $\square$ decision-making \\
\hline$\square$ diversity & $\square$ gender stereotypes & $\square$ discrimination & $\square$ ethics \\
\hline$\square$ executive compensatior & $\square$ leadership & $\square$ job-performance & $\square$ executives \\
\hline$\square$ female executives & $\square$ male executives & $\square$ management & $\square$ gender \\
\hline$\square \begin{array}{l}\text { firm financial } \\
\text { performance }\end{array}$ & $\square$ men & $\square$ metaanalysis & $\square$ managers \\
\hline$\square$ firm perfomance & $\square$ perspective & $\square$ mobility & $\square$ model \\
\hline$\square$ gender diversity & $\square$ power & $\square$ race & $\square$ organizations \\
\hline$\square$ gender-differences & $\square \operatorname{sex}$ & $\square$ sex-differences & $\square$ perceptions \\
\hline$\square$ impact & $\square$ stereotypes & $\square$ top & $\square$ values \\
\hline$\square$ pay & $\square$ success & $\square$ turnover & \\
\hline$\square$ perfomance & $\square$ women executives & $\square$ united-states & \\
\hline$\square$ top management & $\square$ work & $\square$ women & \\
\hline$\square$ upper echelons & & & \\
\hline women director & & & \\
\hline
\end{tabular}

Figure 4. Keywords grouped by clusters. Source: Prepared by the authors. 
Table 7. Top 25 Keyword by number of occurrences.

\begin{tabular}{ccc}
\hline Keyword & Occurrences & Total Link \\
\hline gender & 70 & 259 \\
women & 38 & 157 \\
management & 26 & 105 \\
executives & 22 & 100 \\
organizations & 21 & 97 \\
leadership & 18 & 84 \\
performance & 20 & 77 \\
work & 15 & 67 \\
model & 17 & 65 \\
diversity & 15 & 62 \\
gender differences & 12 & 59 \\
impact & 12 & 57 \\
managers & 13 & 56 \\
firm performance & 13 & 53 \\
men & 13 & 53 \\
perceptions & 10 & 50 \\
female & 11 & 49 \\
metaanalysis & 11 & 49 \\
sex & 9 & 46 \\
turnover & 9 & 46 \\
business ethics & 8 & 45 \\
perspective & 9 & 40 \\
career success & 9 & 39 \\
race & 6 & 38 \\
women executives & 10 & 37 \\
\hline Source: & &
\end{tabular}

Source: Prepared by the authors.

The VOSviewer software also allows for seeing the density of the groups (Figure 5) through a bibliometric density map, in which each node is represented by a scale of colors that reveals the density of the relationships between the keywords (the colors close to red show the areas with the highest density of co-occurrences of keywords and the colors close to yellow and green show the areas with the lowest density of co-occurrences of keywords). The density of a point on a map depends on both the number of neighboring items and the weights of these items. The greater the number of neighboring elements and the smaller the distance between these elements and the point of interest, the greater the density of the element. In addition, the greater the weight of neighboring elements, the greater the density of the elements [29]. Thus, in the central area of the map (red color), due to their significant centrality and co-occurrence, the keywords belonging to the consolidated lines of research, such as "gender" and "women", are located. A group with greater density corresponds with a greater weight and a greater number of co-occurrences within the group.

\subsection{Co-Cites Analysis Results}

This type of analysis is of particular interest in bibliometric studies, because it determines the influence of different authors and their research papers ([30]. One of the main applications of co-cite analysis is to reveal and represent, through maps, different aspects of the intellectual structure and composition of scientific fields, as well as to identify, through time, specialty areas, research fronts and relationships between disciplines and scientific specialties, as well as changes in intellectual structures [31]; on the other hand, [32], one of the first authors to use this approach argues that co-cite is a relationship established by the citing authors, and that, by measuring co-cite strength, we measure the degree of relationship or association between two articles, according to the perception of the population of citing authors.

For the analysis of co-cites, the bibliographic references of the articles analyzed have been used as a unit. A network map of co-cite links between the references has been drawn up (Figure 6), in which those that have been cited more than five times have been 
selected, giving a total of 109 out of 8975 references, which have generated five clusters of documents.

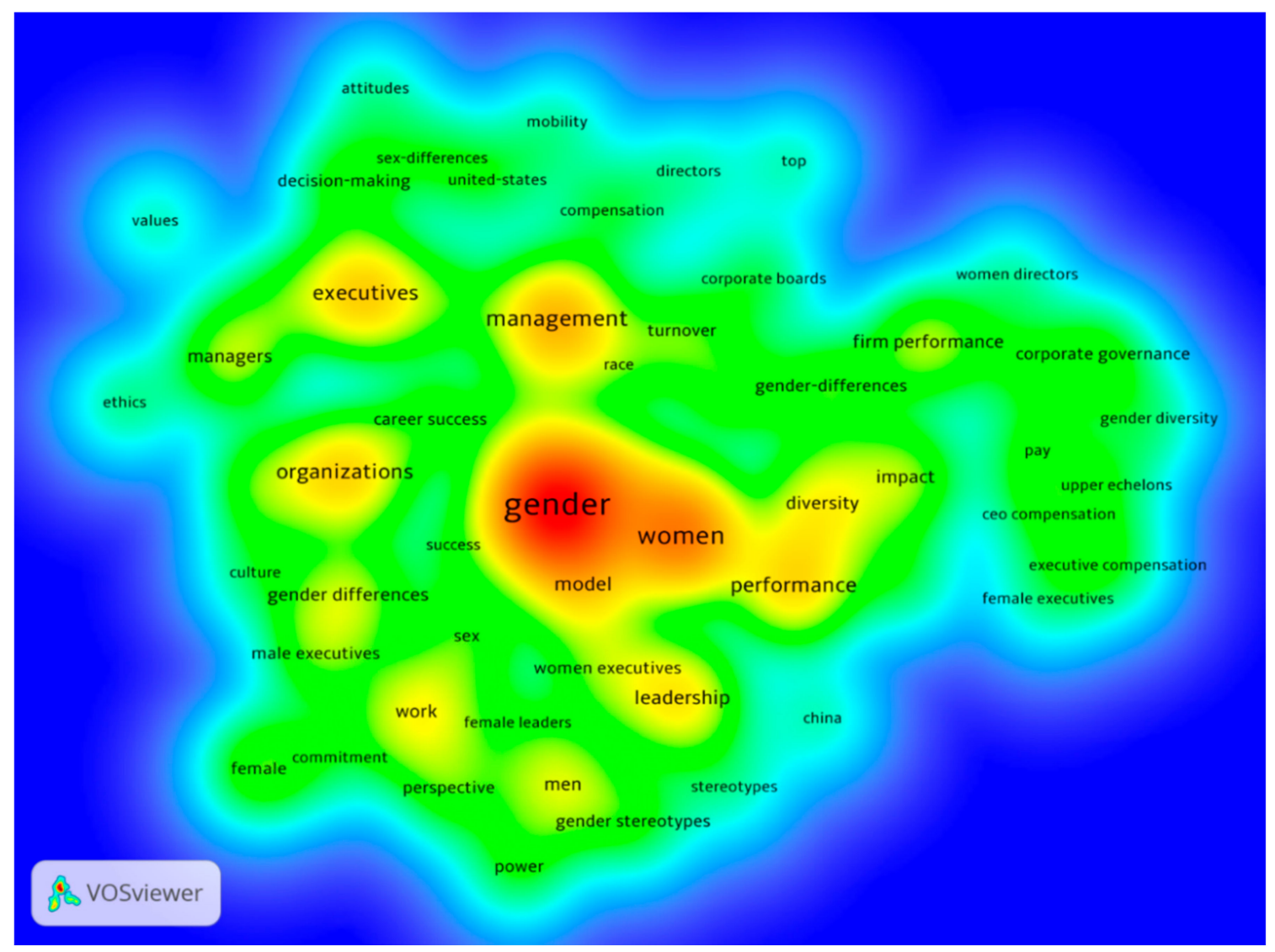

Figure 5. Bibliometric density map (co-words). Source: Prepared by the authors.

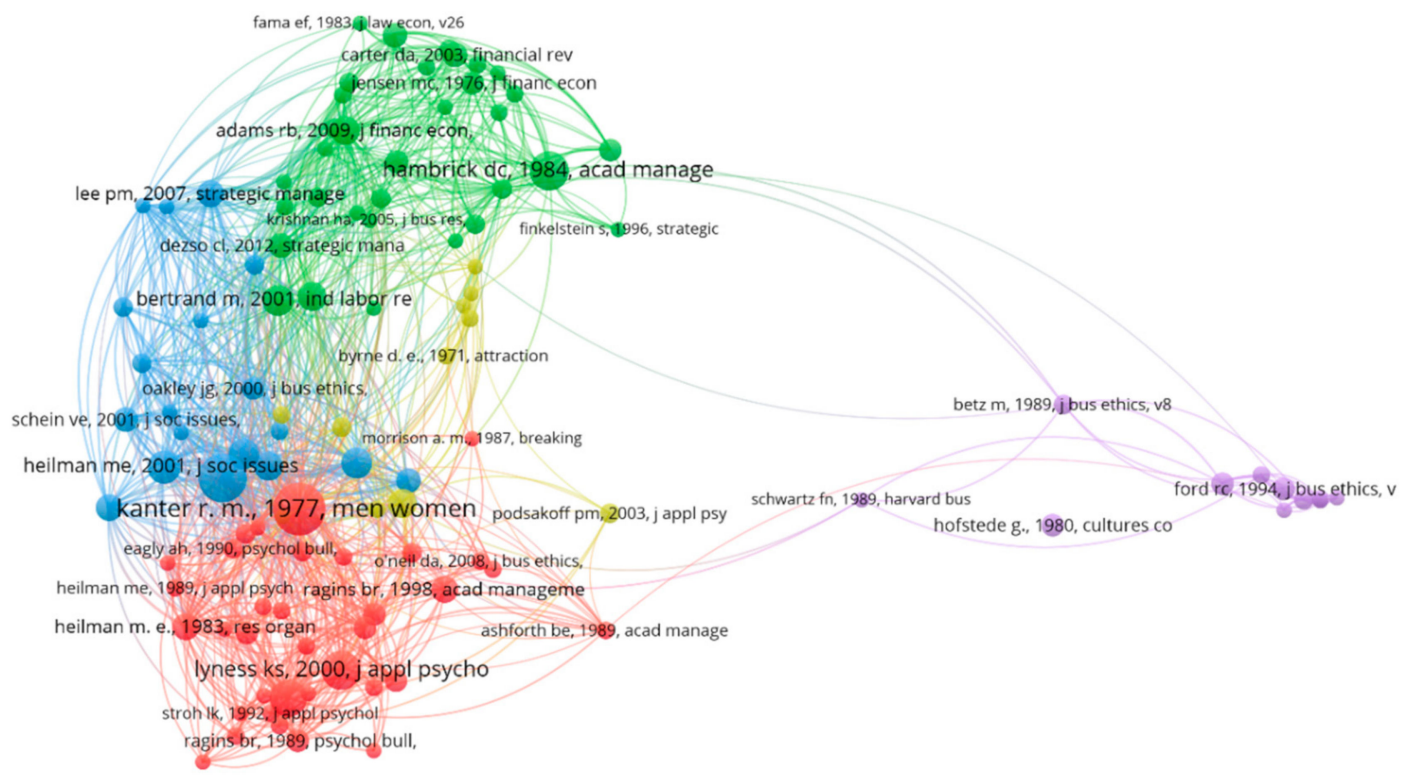

f vosviewer

Figure 6. Co-cite link network. Source: Prepared by the authors. 
Table 8. Classification of the most cited works in each cluster.

\begin{tabular}{cccc}
\hline Cited Reference & Citations & Total Link & Cluster \\
\hline Kanter R.M., 1977 & 23 & 201 & \\
Lyness KS, 2000 & 16 & 118 & 1 \\
Lyness KS, 1997 & 15 & 133 & \\
Heilman M.E., 1983 & 10 & 138 & \\
Ragins BR, 1998 & 10 & 74 & \\
\hline Hambrick DC, 1984 & 16 & 121 & \\
Bertrand M, 2001 & 12 & 107 & \\
Adams RB, 2009 & 11 & 95 & \\
Terjesen S, 2009 & 11 & 108 & \\
Carter DA, 2003 & 9 & 83 & \\
\hline Eagly AH, 2002 & 21 & 222 & \\
Heilman ME, 2001 & 13 & 150 & \\
Eagly AH, 1992 & 12 & 126 & \\
Eagly AH, 1995 & 12 & 114 & \\
Eagly AH, 2007 & 11 & 101 & \\
\hline Eagly AH, 1987 & 11 & 65 & \\
Cohen LE, 1998 & 7 & 30 & \\
Podsakoff PM, 2003 & 7 & 36 & \\
Byrne D.E., 1971 & 6 & 57 & \\
Ibarra H, 1992 & 6 & 26 & \\
\hline Ford RC, 1994 & 8 & 27 & \\
Gilligan C., 1982 & 8 & 36 & \\
Hofstede G., 1980 & 8 & 26 & \\
Betz M, 1989 & 7 & & \\
Trevino LK, 1986 & 7 & 36 & \\
\hline
\end{tabular}

Source: Prepared by the authors.

In order to identify which of the references are marking trends in their respective clusters, a classification has been made with the most cited publications of each, specifying the number of citations of each publication and the strength of its centrality through the total number of links (Table 8).

Once the classification of the clusters resulting from the analysis of co-cites by references has been carried out, the different study tendencies in each of them become evident. The following themes are drawn: career, gender diversity and performance, gender and leadership, organizational behavior and mobility, and gender and ethics (Figure 7).

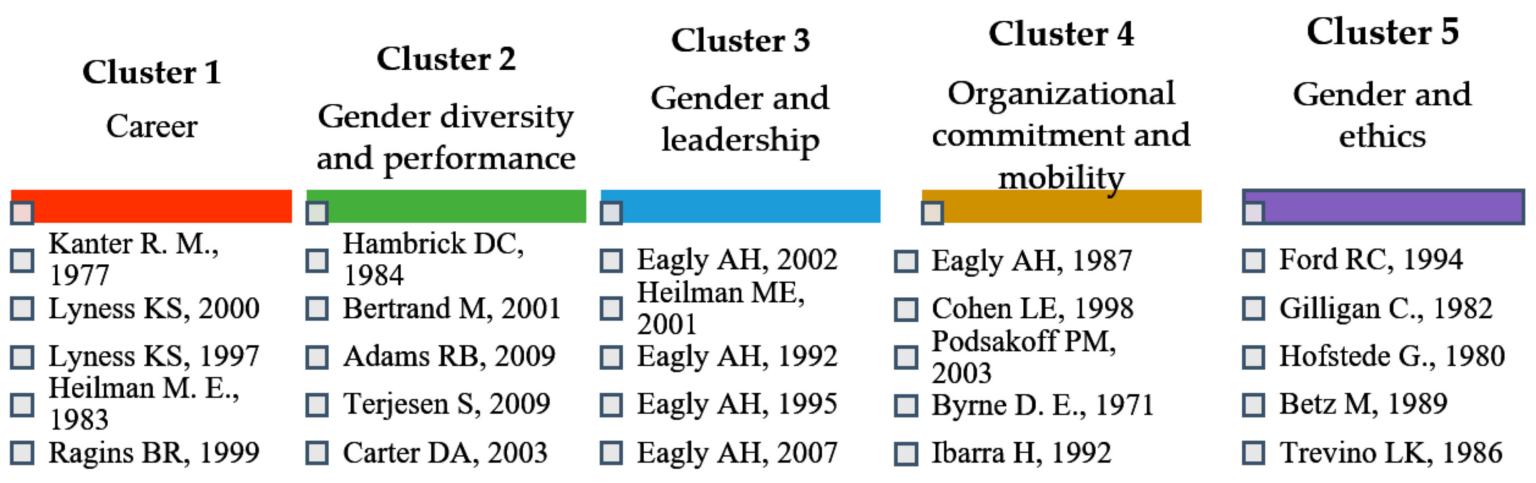

Figure 7. Co-cites grouped by clusters. Source: Prepared by the authors. 


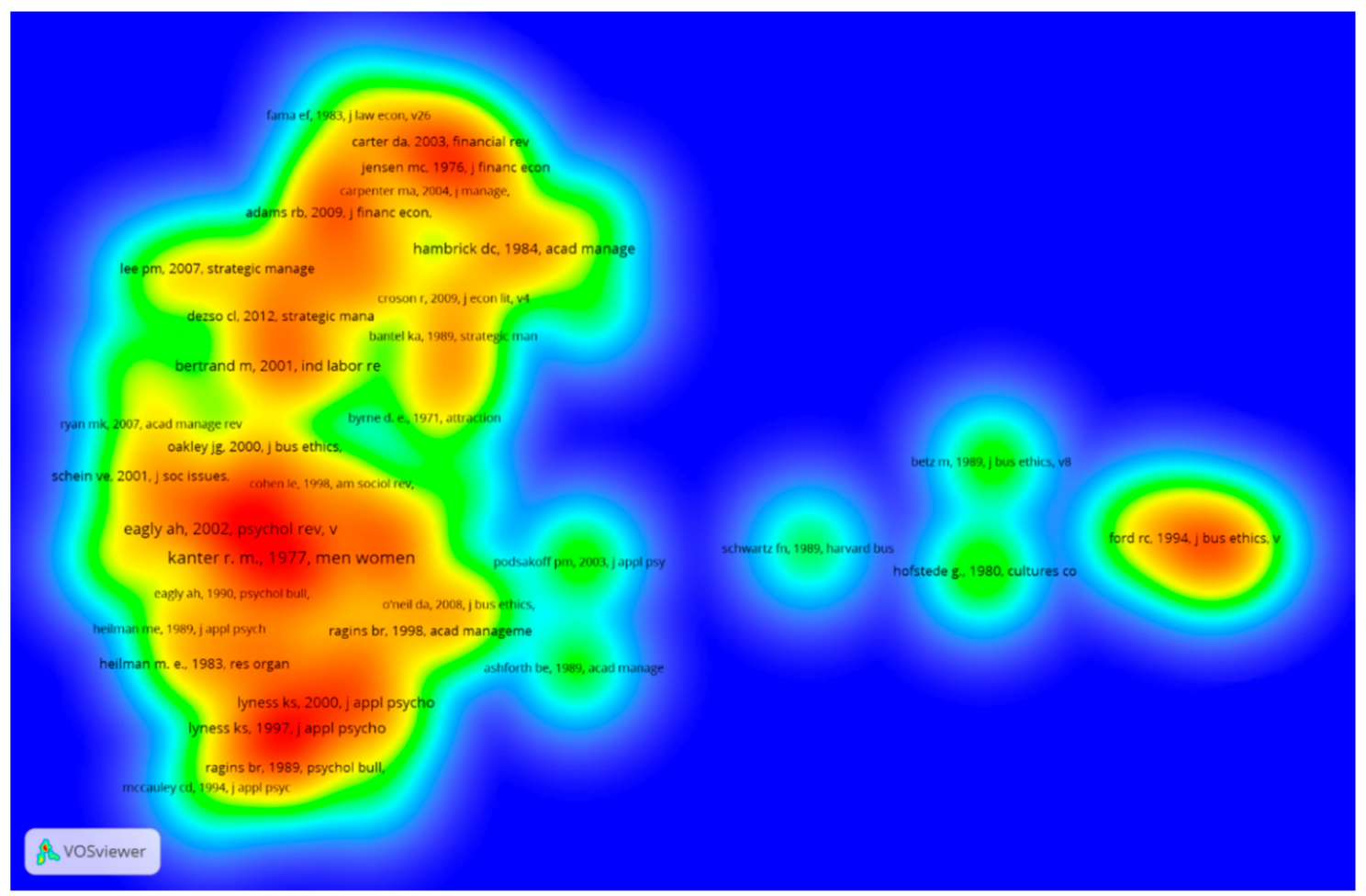

Figure 8. Bibliometric density map (co-cites). Source: Prepared by the authors.

As for cluster 1 , authors, such as $[24,33,34]$ and other authors, have focused on the career and barrier posed by the classic "glass ceiling" theme, as well as the concept of "glass cliff" according to [35]. With respect to cluster 2, the central theme of the work is related to gender diversity on corporate boards and strategies for performance improvement, and how this diversity influences the results, both of the organization and the organizational structure itself ([36-38]. On the other hand, there are works, such as [39], which have focused on the wage gap. In cluster 3, research has generally focused on issues that are related to gender and leadership. Some authors, such as [40], not one of the most active, study the difficulty that women have to become leaders and achieve success with that role or the comparison of effectiveness and leadership between men and women. The case of [41] relates the scarcity of women at the top levels of organizations to gender bias in evaluations. The most prominent content in cluster 4 focuses on research regarding behavioral psychology ([42,43]; or, about inequality in women's organizational mobility and distribution $([44,45]$. Finally, in cluster 5, the works focus primarily on gender and ethics, as well as on issues, such as decision-making and the difference between men and women in ethical behavior ([45-48]) or cultural aspects [49]).

Through the density map of co-cites density (Figure 8), a better perspective of the importance of the relationship between research and authors is obtained. In this way, we can see how one of the densest bulbs is found amongst references from different clusters. In the case of [40] with 21 citations and 222 links (cluster 3) and [33] with 23 citations and 201 links (cluster 1). On the other hand, there is a high concentration of other publications from cluster 1 of the authors [24,34] with 15 and 16 citations and 133 and 118 links, respectively, and [35] with eight citations and 91 links. In cluster 2, there are two focal points of higher density, the first, between [50,51] with nine and five citations and 83 and 55 links, respectively, and the second, Reference [39,52] with nine and 10 citations and 105 and 107 links, respectively. Finally, in cluster 3, which is considerably different from the other clusters, there is a focus of work with greater density around [47], with eight citations and 26 links. 


\section{Discussion}

As mentioned in the introduction, research on gender in business and its organizational structures should not be a consequence of specific social trends or demands, but it should be part of a challenge to achieve a more balanced and balanced society. In this sense, the aim of this work has been to give visibility to, and better understand, the literature that has tried to go deeper into this subject. It should be pointed out that the use of bibliometric techniques and, more specifically, the carrying out of a joint analysis of co-words and co-cites, has allowed for us to carry out a comparison between the component themes of our main object of study, as well as to know the volume of articles on the subject and the evolutionary trends in the field under investigation.

An approximation of how the research has been produced around executive and gender gives us an idea of the wide dispersion of the subject among the authors, also corroborated by the application of Lotka's Law. The number of articles per author has indicated that Lyness is the most prolific author in this field, followed by Ryan; the rest of the scientific production has been written by the first authors, who have only published research on "Gender and executives". The high $\mathrm{H}$ index of these two authors and the low number of articles on this subject leads us to believe that their research is not exclusively focused on this topic. In terms of journals, the most prolific is the Journal of Business Ethics (Q2 JCR). In terms of countries, the USA leads research in this field, along with England and Australia, which also have their highest output in the Q2 JCR quartile.

In relation to the importance of the influence of the subject, it should be noted that social movements, such as the appearance of the "me too" movement in the USA in October 2017 or the publication in Spain of Law 3/2007 on effective equality between men and women, have influenced the increase in scientific production in this field of study. Likewise, it has been detected that the issue of gender is dealt with jointly with other issues, such as ethnicity, religion, socio-economic classes, or exclusion groups, so it is concluded that gender can also be an indicator of discrimination in the labor field. The creation of social enterprises through open innovation requires the incorporation of diversity characteristics, such as gender, on company boards, and management teams, as noted in [53].

\section{Conclusions}

The aims of this work have been to give visibility to the literature that is related to Executive and Gender. Bibliometric techniques have been used on a set of 144 articles from Web of Science (WoS) indexed journals between 1992 and 2018. The scientific area is considered to be dispersed and not yet sufficiently developed. With regard to the evolution of published research, although, with certain ups and downs, the line has been upward and, above all, between 2017 and 2018. The results suggest, in a first conclusion, that the most recurrent themes in scientific production are "Gender and promotion", "Gender diversity", "Ethics", "Work-life balance", or "Gender and HR". A second conclusion shows, as a result of the co-word analysis, that the main lines of research focus on four groups, and that they shed light on issues, such as diversity and its impact on organizations, gender power and leadership, wage discrimination, compensation and mobility, as well as on aspects related to ethics, values, and organizational culture. For its part, the analysis of the cocitos, in addition to endorsing these four clusters, has revealed a fifth cluster with the theme "career and glass cliff", which reveals access to precarious and risky leadership in the case of women $([19,20])$.

In terms of the application of the research, the authors suggest that the results of this study can be used to draw conclusions not only for the academic world, and they can serve as a guide for future research, but also for business practice.

\subsection{Limitations}

The authors acknowledge that this research has some limitations. In the first place, those that are related to the limitation that comes from the use of a single database (WoS), in addition to that produced by the filters applied in the search. Secondly, those that could 
be given by the possible conceptual derivations of the subject and that, when attempting a compromise between the results and complexity, have not been contemplated in the search. The authors believe that, despite the limitations, the results are based on a contrasting methodology and they suggest some valuable conclusions for the expansion of knowledge of the field under study.

\subsection{Future Research}

In general, the analysis as a whole suggests, contrary to what one might initially think, that this is an emerging scientific area that is not yet sufficiently developed, both in terms of the number of articles published and the number of authors focusing on this line of research. This gives rise to future lines that are related to very current social issues in the business sphere, such as discrimination against women, sexism, equality, or family reconciliation, without abandoning the central "Management and Gender" axis which we have maintained in this work. We have detected, as a result of the analysis carried out, that it is necessary to go deeper into concepts, such as the "glass cliff", in order to investigate the causes of the existence of this phenomenon, as well as to propose the measures to be adopted to ensure this equality, merit, and capacity when accessing management positions in companies.

It should be borne in mind that the searches have only focused on scientific articles in successive studies, and could also be extended to books and other scientific texts. These searches have been carried out on the Web of Science database and only journals indexed in Journal Citation Reports or Scopus, and other databases of SJR (Scimago Journal \& Country Rank) or ABDC (Australian Business Deans Council) could be included in the future. In addition, new JCR categories, such as culture or sociology, can be used, given the cross-cutting nature of the subject. This will give a broader view of the subject studied and it may suggest other emerging lines in borderline fields.

Finally, it is necessary to refer to recent phenomena, such as open citations, new instruments of bibliometric analysis, or modern citation indexes. In recent years, new sources of citations have begun to emerge, such as Dimensions (proprietary) and the Corpus of Open Citations (open). These instruments generally accept the contributions of citation indices and, consequently, scientific mapping instruments are still under active development. VOSViewer, Citespace, or newer tools, such as Citation Gecko, have started to respond to the trend of new emerging citation indices and they have begun to support these new sources in addition to traditional Web of Science and Scopus data as [54] points out. Similarly, the popular Publish or Perish tool, which began by supporting the extraction of results and citations from Google Scholar, Microsoft Academic graph, or Crossref, has now grown to also support other recent citation indices. This interesting scenario, together with the wide dispersion among the authors in this field, may lead, on the one hand, to new lines of research and, on the other, to reinforce and consolidate some of the already emerging ones.

Author Contributions: Conceptualization, M.R.-F., E.M.S.-T. and J.H.-B.; methodology, M.R.-F., E.M.S.-T. and J.H.-B.; software, E.M.S.-T. and J.H.-B.; validation, M.R.-F.; formal analysis, M.R.-F., E.M.S.-T. and J.H.-B.; investigation, M.R.-F., E.M.S.-T. and J.H.-B.; resources, M.R.-F., E.M.S.-T. and J.H.-B.; writing-original draft preparation, M.R.-F., E.M.S.-T. and J.H.-B.; writing-review and editing, M.R.-F., E.M.S.-T. and J.H.-B.; visualization and supervision, M.R.-F.; project administration, M.R.-F., E.M.S.-T. and J.H.-B. All authors have read and agreed to the published version of the manuscript.

Funding: This research received no external funding.

Institutional Review Board Statement: Not applicable.

Informed Consent Statement: Not applicable.

Acknowledgments: We are very grateful to University of Malaga.

Conflicts of Interest: The authors declare no conflict of interest. 


\section{References}

1. Thomas, K.W.; Thomas, G.F.; Schaubhut, N. Conflict styles of men and women at six organization levels. Int. J. Confl. Manag. 2008, 19, 148-166. [CrossRef]

2. Bauer, G.; Burnet, J.E. Gender quotas, democracy, and women's representation in Africa: Some insights from democratic Botswana and autocratic Rwanda. Womens Stud. Int. Forum 2013, 41, 103-112. [CrossRef]

3. Dickes, L.A.; Crouch, E. Policy effectiveness of US governors: The role of gender and changing institutional powers. Womens Stud. Int. Forum 2015, 53, 90-98. [CrossRef]

4. Lee, S.H. How Do Women in Developing Countries Increase Political Representation in National Assemblies? A Longitudinal Analysis of South Korea. J. Women Politics Policy 2015, 36, 161-190. [CrossRef]

5. Sanghvi, M.; Hodges, N. Marketing the female politician: An exploration of gender and appearance. J. Mark. Manag. 2015, 31, 1676-1694. [CrossRef]

6. Kuntz, J.R.C.; Kuntz, J.R.; Elenkov, D.; Nabirukhina, A. Characterizing Ethical Cases: A Cross-Cultural Investigation of Individual Differences, Organisational Climate, and Leadership on Ethical Decision-Making. J. Bus. Ethics 2013, 113, 317-331. [CrossRef]

7. King, E.B.; Rogelberg, S.G.; Hebl, M.R.; Braddy, P.W.; Shanock, L.R.; Doerer, S.C.; McDowell-Larsen, S. Waistlines and Ratings of Executives: Does Executive Status Overcome Obesity Stigma? Hum. Resour. Manag. 2016, 55, 283-300. [CrossRef]

8. Ali, F.H.; Ali, M.; Malik, S.Z.; Hamza, M.A.; Ali, H.F. Managers' Open Innovation and Business Performance in SMEs: A Moderated Mediation Model of Job Crafting and Gender. J. Open Innov. Technol. Mark. Complex. 2020, 6, 89. [CrossRef]

9. Mansoor, M.; Ellahi, N.; Hassan, A.; Malik, Q.A.; Waheed, A.; Ullah, N. Corporate Governance, Shariah Governance, and Credit Rating: A Cross-Country Analysis from Asian Islamic Banks. J. Open Innov. Technol. Mark. Complex. 2020, 6, 170. [CrossRef]

10. Mirza, N.I.; Malik, Q.A.; Mahmood, C.K. The Value of Board Diversity in the Relationship of Corporate Governance and Investment Decisions of Pakistani Firms. J. Open Innov. Technol. Mark. Complex. 2020, 6, 146. [CrossRef]

11. Callon, M.; Courtial, J.P.; Turner, W.A.; Bauin, S. From translations to problematic networks: An introduction to co-word analysis. Soc. Sci. Inf. 1983, 22, 191-235. [CrossRef]

12. Whittaker, J. Creativity and conformity in science: Titles, keywords, and co-word analysis. Soc. Stud. Sci. 1998, 19, 473-496. [CrossRef]

13. Peters, H.P.D.; Van Raan, A.F.J. Structuring scientific activities by co-author analysis. Scientometrics 1991, 20, 235-255. [CrossRef]

14. Upham, S.P.; Small, H. Emerging research fronts in science and technology: Patterns of new knowledge development. Scientometrics 2010, 83, 15-38. [CrossRef] [PubMed]

15. Miller, J.G.; Wheeler, K.G. Unraveling the mysteries of gender differences in intentions to leave the organization. J. Organ. Behav. 1992, 13, 465-478. [CrossRef]

16. Yanadori, Y.; Gould, J.A.; Kulik, C.T. A fair go? The gender pay gap among corporate executives in Australian firms. Int. J. Hum. Resour. Manag. 2018, 29, 1636-1660. [CrossRef]

17. Chaudhary, R. Corporate Social Responsibility and Employee Performance: A Study Among Indian Business Executives. Int. J. Hum. Resour. Manag. 2018, 31, 1-24. [CrossRef]

18. Adams-Harmon, D.; Greer-Williams, N. Successful ascent of female leaders in the pharmaceutical industry: A qualitative, transcendental, and phenomenological study. Equal. Divers. Incl. Int. J. 2020. [CrossRef]

19. Glass, C.; Cook, A. Leading at the top: Understanding women's challenges above the glass ceiling. Leadersh. Q. 2016, 27, 51-63. [CrossRef]

20. Ryan, M.K.; Haslam, S.A.; Morgenroth, T.; Rink, F.; Stoker, J.; Peters, K. Getting on top of the glass cliff: Reviewing a decade of evidence, explanations, and impact. Leadersh. Q. 2016, 27, 446-455. [CrossRef]

21. Joshi, A.; Son, J.; Roh, H. When can women close the gap? A meta-analytic test of sex differences in performance and rewards. Acad. Manag. J. 2015, 58, 1516-1545. [CrossRef]

22. Groysberg, B.; Abrahams, R. Manage Your Work, Manage Your Life. Harv. Bus. Rev. 2014, 92, 58.

23. Buttner, E.H.; Moore, D.P. Women's organizational exodus to entrepreneurship: Self-reported motivations and correlates with success. J. Small Bus. Manag. 1997, 35, 34-46.

24. Lyness, K.S.; Thompson, D.E. Climbing the corporate ladder: Do female and male executives follow the same route? J. Appl. Psychol. 2000, 85, 86-101. [CrossRef]

25. Kulich, C.; Trojanowski, G.; Ryan, M.K.; Haslam, S.A.; Renneboog, L.D.R. Who gets the carrot and who gets de stick? Evidence of gender disparities in executive remuneration. Strat. Manag. J. 2011, 32, 301-321. [CrossRef]

26. Stafsudd, A. People are strange when you're a stranger: Senior executives select similar successors. Eur. Manag. Rev. 2006, 3 , 177-189. [CrossRef]

27. Krishnan, G.V.; Parsons, L.M. Getting to the bottom line: An exploration of gender and earnings quality. J. Bus. Ethics 2008, 78, 65-76. [CrossRef]

28. Belot, F.; Serve, S. Earnings Quality in Private SMEs: Do CEO Demographics Matter? J. Small Bus. Manag. 2018, 56, 323-344. [CrossRef]

29. Van Eck, N.J.; Waltman, L. Software survey: VOSviewer, a computer program for bibliometric mapping. Scientometrics 2010, 84, 523-538. [CrossRef]

30. Lin, A.J.; Hsu, C.L.; Chiang, C.H. Bibliometric study of electronic commerce research in information systems \& MIS journals. Scientometrics 2016, 109, 1455-1476. [CrossRef] 
31. Miguel, S.; Moya Anegón, F.D.; Herrero Solana, V. The analysis of co-citas as a research method in Library and Information Science. Libr. Res. 2007, 21, 139-155. [CrossRef]

32. Small, H. Co-citation in the scientific literature: A new measure of the relationship between two documents. J. Am. Soc. Inf. Sci. 1973, 24, 265-269. [CrossRef]

33. Kanter, R.M. Men and Women of the Corporation; Basic Books: New York, NY, USA, 1977.

34. Lyness, K.S.; Thompson, D.E. Above the glass ceiling? A comparison of matched samples of female and male executives. J. Appl. Psychol. 1997, 82, 359-375. [CrossRef] [PubMed]

35. Ragins, B.R.; Scandura, T.A. Burden or blessing? Expected costs and benefits of being a mentor. J. Organ. Behav. 1999, 20, 493-509. [CrossRef]

36. Hambrick, D.; Mason, P. Upper Echelons: The Organization as a Reflection of Its Top Managers. Acad. Manag. Rev. 1984, 9, 193-206. [CrossRef]

37. Adams, S.M.; Gupta, A.; Leeth, J.D. Are Female Executives Over-represented in Precarious Leadership Positions? Br. J. Manag. 2009, 20, 1-12. [CrossRef]

38. Terjesen, S.; Sealy, R.; Singh, V. Women Directors on Corporate Boards: A Review and Research Agenda. Corp. Gov. Int. Rev. 2009, 17, 320-337. [CrossRef]

39. Bertrand, M.; Hallock, K. The Gender Gap in Top Corporate Jobs. Ind. Labor Relat. Rev. 2001, 55, 3-21. [CrossRef]

40. Eagly, A.; Karau, S. Role Congruity Theory of Prejudice Toward Female Leaders. Psychol. Rev. 2002, 109, 573-598. [CrossRef]

41. Heilman, M. Description and Prescription: How Gender Stereotypes Prevent Women's Ascent Up the Organizational Ladder. J. Soc. Issues 2001, 57, 657-674. [CrossRef]

42. Eagly, A.H. Sex Differences in Social Behavior: A Social-Role Interpretation; Erlbaum: Hillsdale, NJ, USA, 1987.

43. Podsakoff, P.; Mackenzie, S.; Lee, J.; Podsakoff, N. Common Method Biases in Behavioral Research: A Critical Review of the Literature and Recommended Remedies. J. Appl. Psychol. 2003, 88, 879-903. [CrossRef]

44. Ibarra, H. Homophily and Differential Returns: Sex Differences in Network Structure and Access in an Advertising Firm. Adm. Sci. Q. 1992, 37, 422. [CrossRef]

45. Cohen, L.; Broschak, J.; Haveman, H. And Then There were More? The Effect of Organizational Sex Composition on the Hiring and Promotion of Managers. Am. Sociol. Rev. 1998, 63, 711. [CrossRef]

46. Betz, M.; O'Connell, L.; Shepard, J. Gender differences in proclivity for unethical behavior. J. Bus. Ethics 1989, 8, 321-324. [CrossRef]

47. Ford, R.; Richardson, W. Ethical decision making: A review of the empirical literature. J. Bus. Ethics 1994, 13, 205-221. [CrossRef]

48. Trevino, L. Ethical Decision Making in Organizations: A Person-Situation Interactionist Model. Acad. Manag. Rev. 1986, 11, 601. [CrossRef]

49. Hofstede, G. Culture's Consequences: International Differences in Work-Related Values; Sage Publications: Beverly Hills, CA, USA, 1980.

50. Carter, D.A.; Simkins, B.J.; Simpson, W.G. Corporate Governance, Board Diversity, and Firm Value. Financial Rev. 2003, 38 , 33-53. [CrossRef]

51. Jensen, M.C.; Meckling, W.H. Theory of the Firm: Managerial Behavior, Agency Costs and Ownership Structure. J. Financ. Econ. 1976, 3, 305-360. [CrossRef]

52. Dezsö, R. Does Female Representation in Top Management Improve Firm Performance? A Panel Data Investigation. Strateg. Manag. J. 2012, 1072-1089. [CrossRef]

53. Svirina, A.; Zabbarova, A.; Oganisjana, K. Implementing open innovation concept in social business. J. Open Innov. Technol. Mark. Complex 2016, 2, 20. [CrossRef]

54. Tay, A. The Rise of New Citation Indexes and the Impact on Science Mapping Tools-Citespace, Vosviewer. Citation Gecko and more. 2019. Available online: http:/ / musingsaboutlibrarianship.blogspot.com/2019/09/the-rise-of-new-citation-indexes-and_5. html (accessed on 21 May 2019). 